\title{
Fetal diabetes in rats and its effect on placental glycogen
}

\author{
V.Barash, A.Gutman and E. Shafrir \\ Department of Clinical Biochemistry, Hadassah University Hospital and Hebrew University - Hadassah Medical School, Jerusalem, Israel
}

\begin{abstract}
Summary. The role of fetal insulin in placental glycogen accumulation, which occurs despite insulin deficiency in maternal diabetes, was studied in rats. Streptozotocin was injected into fetuses of non-diabetic and streptozotocin-diabetic mothers on days 19.5 and 20.5 of gestation, causing fetal hypoinsulinaemia and pancreatic insulin depletion. Placental glycogen content of either $1.6 \mathrm{mg} / \mathrm{g}$ in non-diabetic rats or $6.5 \mathrm{mg} / \mathrm{g}$ in diabetic rats was not affected by fetal streptozotocin treatment. Glycogen distribution was also measured in the placenta to assess the effect of fetal hypoinsulinaemia on glycogen content in its fetal segment. The glycogen concentration ratio between the fetal and maternal segments in diabetic rats was $\sim 0.3$ and increased to $\sim 0.5$ in diabetic rats, without being affected by fetal hypoinsulinaemia. There was no significant effect of fetal hypoinsulinaemia on the activities of placental glycogen synthase or glycogen phosphorylase, both in nondiabetic and diabetic rats. Fetal hypoinsulinaemia was associated, however, with a marked decrease in fetal liver glycogen
\end{abstract}

together with a decrease in fetal liver weight, which was more pronounced than the decrease in fetal body weight. Administration of insulin to the streptozotocin-treated fetuses restored the impaired glycogen synthesis (measured by incorporation of $\mathrm{U}-\left[{ }^{14} \mathrm{C}\right]$-glucose and ${ }^{3} \mathrm{H}_{2} \mathrm{O}$ in the fetal liver) without affecting glycogen synthesis in the placenta. These results demonstrate: (1) placental glycogen metabolism in contrast to fetal liver glycogen metabolism, is not regulated by fetal insulin; (2) the reduced fetal liver weight and its glycogen content, rather than hyperglycaemia, are the salient features of fetal insulin deficiency; and (3) placental glycogen accumulation in diabetes is related to the hyperglycaemia of maternal origin and not to the changes in maternal or fetal insulin availability.

Key words: Placenta, fetal liver, fetal hypoinsulinaemia, glycogen content and synthesis, insulin, hyperglycaemia, glycogen synthase, glycogen phosphorylase, rat.
The regulatory role of insulin in glycogen metabolism in muscle and liver has been well clarified [1-3], whereas the effect of insulin on placental glycogen metabolism has not been established. In a few studies in vitro, it was claimed that insulin accelerates glycogen synthesis [4, 5], but in other reports no effect of insulin has been demonstrated $[6,7]$.

In a previous study [8] we showed, similarly to others [9-11], that glycogen accumulates in the placenta during maternal insulin deficiency in diabetic rats and in diabetic women [12-14]. The accumulation of glycogen was not associated with enzymatic changes favouring glycogen deposition, since the activities of glycogen synthase and phosphorylase were both found to be increased $[8,11]$. The accumulation of placental glycogen in diabetes was suggested to be due to the abundance of glucose supplied by the maternal circulation and the resultant intracellular elevation of glucose-6-phosphate [8].
The role of fetal insulin on the metabolism of placental glycogen has hitherto not been considered. In late pregnancy the level of insulin in the fetal circulation is elevated [15-17], particularly in the presence of maternal hyperglycaemia $[18,19]$. Thus, the maternal side of the placenta is exposed to normo- or hypoinsulinaemia in non-diabetic or diabetic mothers, respectively, whereas the fetal side of the placenta is facing hyperinsulinaemia. In the present study we have induced fetal hypoinsulinaemia to explore its effect on placental glycogen metabolism, on a comparative basis with the effect on fetal liver.

\section{Material and methods}

\section{Animal treatment and tissue preparation}

Pregnant (overnight mating) albino rats of the Hebrew University strain, weighing $240-280 \mathrm{~g}$, were maintained on standard laboratory chow and water ad libitum. The $12 \mathrm{~h}$ following the overnight mating 
Table 1. Glucose and insulin levels in maternal and fetal serum and in fetal pancreas of control and STZ-diabetic pregnant rats as well as control and STZ-injected fetuses

\begin{tabular}{|c|c|c|c|c|c|c|c|c|}
\hline \multirow{3}{*}{$\begin{array}{l}\text { Pregnant } \\
\text { rats }\end{array}$} & \multicolumn{2}{|c|}{ Maternal sera } & \multicolumn{4}{|l|}{ Fetal sera } & \multirow{2}{*}{\multicolumn{2}{|c|}{$\frac{\text { Fetal pancreas }}{\text { Insulin (mU/pancreas) }}$}} \\
\hline & \multirow{2}{*}{$\begin{array}{l}\text { Glucose } \\
(\mathrm{mmol} / \mathrm{l})\end{array}$} & \multirow{2}{*}{$\begin{array}{l}\text { Insulin } \\
(\mathrm{mU} / \mathrm{l})\end{array}$} & \multicolumn{2}{|c|}{ Glucose $(\mathrm{mmol} / \mathrm{l})$} & \multicolumn{2}{|c|}{ Insulin $(\mathrm{mU} / \mathrm{l})$} & & \\
\hline & & & Control & STZ-injected & Control & STZ-injected & Control & STZ-injected \\
\hline Control & $4.9 \pm 0.2$ & $45 \pm 6$ & $2.6 \pm 0.3$ & $3.5 \pm 0.4$ & $84 \pm 6$ & $29 \pm 5^{c}$ & $55.2 \pm 4.1$ & $14.9 \pm 1.9^{\mathrm{a}}$ \\
\hline Diabetic & $18.3 \pm 1.9^{\mathrm{b}}$ & $14 \pm 3^{b}$ & $11.9 \pm 0.6^{\mathrm{b}}$ & $15.0 \pm 0.9^{b c}$ & $106 \pm 7^{a}$ & $18 \pm 4^{c}$ & $13.8 \pm 1.6^{\mathrm{b}}$ & $9.0 \pm 1.3^{\mathrm{ac}}$ \\
\hline
\end{tabular}

Values in maternal sera are mean \pm SEM for groups of 16-18 rats. Values in fetal sera represent 8-10 pools, each from to six fetuses of the same litter. Values in fetal pancreas were determined in extracts of pancreas of individual fetuses ( 14 control and 12 STZ-injected). ${ }^{a} p<0.05$, difference between control and STZ injected fetuses; ${ }^{\mathrm{b}} p<0.01$ at least, difference between control and STZ-injected rats or fetuses; ${ }^{\mathrm{c}} p<0.05$ at least, difference between control and STZ-injected fetuses of the same litters

Table 2. Glycogen content of placenta and fetal liver and placental, fetal and fetal liver weights in normal and diabetic rats

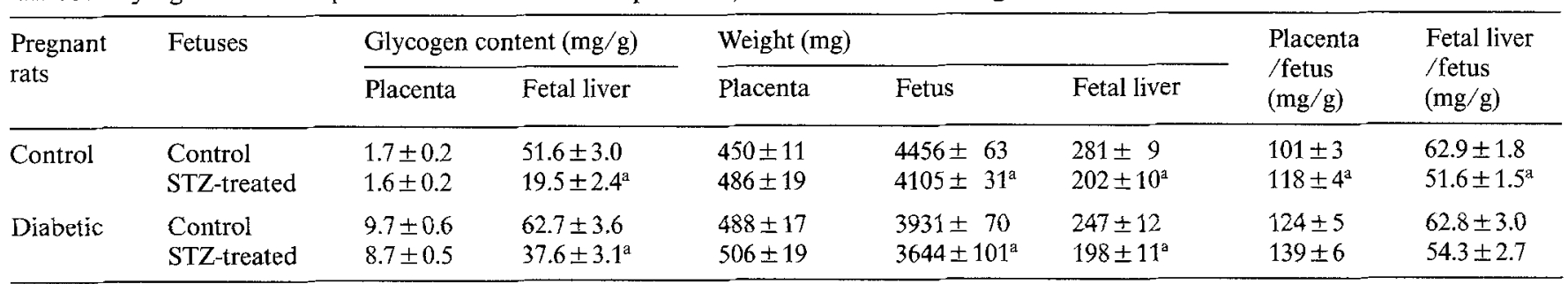

Values are mean \pm SEM for groups of 12-16 rats. The values for each rat are derived from an average of four to six placentas, fetuses or fetal livers of the litter. ${ }^{a} p<0.05$ at least, difference between STZ-injected and control fetuses

were counted as $1 / 2$ day of pregnancy. In one group, diabetes was induced on day 13.5 of gestation by intraperitoneal injection of streptozotocin (STZ, $55 \mathrm{mg} / \mathrm{kg}$ body weight) in citrate buffer $(5 \mathrm{mmol} / 1, \mathrm{pH}$ 4.5). The control group was injected with buffer only. Fetuses of nondiabetic and diabetic rats were injected twice with STZ, on days 19.5 and 20.5 of gestation, similarly to the procedure used by Portha et al. [20]. The rats were lightly anaesthetised with ether, the abdomen was opened by mid-line incision and the two horns of the uterus were exposed. Starting from one end of the uterus, the fetuses were injected on each day with STZ ( $240 \mu \mathrm{g} /$ fetus in $5 \mu \mathrm{l}$ citrate buffer). Control fetuses received $5 \mu \mathrm{l}$ of citrate buffer alone, starting from the opposite end of the second horn. The injection was given through the uterus and the amniotic sac into the fetal peritoneum by "Microliter No 701" $(10 \mu$ l syringe, Hamilton, Co Reno, NE, USA) with a fine needle. On day 21.5 of gestation, the rats were decapitated, blood was collected and the fetuses were removed immediately. Fetal blood was collected into glass capillary tubes by an incision of the carotid artery and separately pooled from the STZ-injected and control fetuses from each rat, within $3 \mathrm{~min}$ after decapitation. The placenta, maternal and fetal livers were quickly taken for glycogen determination or frozen in liquid air and stored at $-70^{\circ} \mathrm{C}$ for enzyme assays. Fetal pancreas was excised and homogenized in $0.15 \mathrm{~mol} / \mathrm{h} \mathrm{HCl}$ in $75 \%$ ethanol (vol/voi) for insulin assays, as in previous studies [21].

In several experiments the placenta was divided into two parts by gentle separation of the outer decidual zone and the inner spongiosalabyrinth zone. Microscopic examination revealed that the separated inner segment was totally composed of fetal villi and the spongiosa layer, therefore, was taken to represent the "fetal" part of the placenta. The outer segment of the placenta contained on its inner surface a few remnants of the fetal spongiosa, but its bulk represented the 'maternal' part of the placenta.

\section{Metabolic and enzyme assays}

Serum glucose was determined by a hexokinase method (BoeringerMannheim FRG). Insulin was determined by a magnetic antibody immunoassay (MAIAKIT, Serono, Italy), using human insulin as a standard.
For the determination of glycogen synthase and phosphorylase activities [8], portions of frozen placentas were homogenized in five volumes on ice-cold Hepes buffer $(50 \mathrm{mmol} / 1$, Sigma Chemicals, St. Louis, MO, USA), $\mathrm{pH} 7.4$, containing sodium fluoride $(50 \mathrm{mmol} / \mathrm{l})$. The homogenate was centrifuged at $600 \mathrm{~g}$ for $10 \mathrm{~min}$, and the supernatant fluid was used for enzyme assays. The homogenate protein content was determined by the method of Lowry et al. [22]. Activity of gly. cogen synthase and phosphorylase was expressed as $\mathrm{nmol} / \mathrm{min}$ of glucose incorporated into glycogen from UDP $\left[{ }^{14} \mathrm{C}\right]$-glucose or $\left[{ }^{14} \mathrm{C}\right]$ glucose-1-phosphate, respectively, per mg of homogenate protein.

Glycogen content of the placenta and fetal liver was determined as glucose, after digestion of the tissues with $30 \%$ (wt $/ \mathrm{vol}$ ) potassium hydroxide, followed by precipitation at $60 \%$ (vol $/ \mathrm{vol})$ ethanol and enzymatic hydrolysis of glycogen [23].

\section{In vivo incorporation of ${ }^{3} \mathrm{H}$ - and ${ }^{14} \mathrm{C}$-label into placental and fetal liver glycogen}

The fetuses of pregnant rats were all injected with STZ on days 19.5 and 20.5 of gestation, as described above. On day 21 , the rats were lightly anaesthetised with ether, the fetuses were exposed and those on one horn of the uterus injected intraperitoneally each with a mixture of $5 \mathrm{mU}$ of regular insulin (Lilly) and $50 \mathrm{mU}$ of Lente insulin (Novo), in a final volume of $5 \mu$ l. Control fetuses on the other horn of the uterus received $5 \mu \mathrm{l}$ of $\mathrm{NaCl}$ solution $(0.154 \mathrm{mmol} / \mathrm{l})$. The abdomen was then resutured. After $2 \mathrm{~h}$, the rats were injected intraperitoneally with $20 \mathrm{mCi}$ of ${ }^{3} \mathrm{H}_{2} \mathrm{O}$ and $30 \mu \mathrm{Ci}$ of $\mathrm{U}-\left[{ }^{14} \mathrm{C}\right]$-glucose (Amersham International, Amersham, Bucks., UK) in tracer amounts. After further $4 \mathrm{~h}$, the rats were decapitated and the fetuses were removed. The placentas and fetal livers were promptly digested in $30 \% \mathrm{KOH}$ solution, glycogen was isolated and its radioactivity determined as described previously [24].

\section{Statistical analysis}

Statistical comparisons were carried out by Student's $t$ test for unpaired series. 
Table 3. Effect of intrafetal insulin administration to STZ-treated fetuses of non-diabetic rats on the incorporation of ${ }^{3} \mathrm{H}_{2} \mathrm{O}$ and $\mathrm{U}-\left[{ }^{14} \mathrm{C}\right]-$ glucose label into placental and fetal hepatic glycogen

\begin{tabular}{|c|c|c|c|c|}
\hline \multirow[t]{3}{*}{$\begin{array}{l}\text { Treatment } \\
\text { of fetuses }\end{array}$} & \multicolumn{2}{|c|}{$\begin{array}{l}\text { Incorporation into } \\
\text { fetal liver glycogen }\end{array}$} & \multicolumn{2}{|c|}{$\begin{array}{l}\text { Incorporation into } \\
\text { placental glycogen }\end{array}$} \\
\hline & {$\left[{ }^{3} \mathrm{H}\right]$} & {$\left[{ }^{14} \mathrm{C}\right]$} & {$\left[{ }^{3} \mathrm{H}\right]$} & {$\left[{ }^{14} \mathrm{C}\right]$} \\
\hline & \multicolumn{2}{|c|}{ (dpm/mg tissue) } & \multicolumn{2}{|c|}{ (dpm/mg tissue) } \\
\hline STZ & $4.9 \pm 0.4$ & $7.8 \pm 1.0$ & $3.4 \pm 0.3$ & $3.8 \pm 0.5$ \\
\hline STZ+ insulin & $15.1 \pm 1.1^{\mathrm{a}}$ & $22.2 \pm 1.8^{\mathrm{a}}$ & $3.9 \pm 0.4$ & $5.1 \pm 0.8$ \\
\hline
\end{tabular}

Values are mean \pm SEM for four litters from four different rats. Each litter comprised 8-10 fetuses, all injected with STZ, half of them on one horn of the uterus, treated with insulin. ${ }^{a} p<0.005$

\section{Results}

\section{Effect of STZ on maternal and fetal glucose and insulin levels}

In pregnant rats, with diabetes induced on day 13.5 of gestation, a marked decrease in serum insulin and increase in serum glucose levels was seen on day 21.5 of gestation (Table 1). In control and STZ-treated fetuses of the same litter from non-diabetic rats, serum glucose concentrations were not significantly different. In control and STZ-treated fetuses of the same litters from diabetic rats, marked hyperglycaemia was seen, as expected. The glucose level in STZ-injected fetuses of diabetic rats was slightly, though significantly, higher than in control fetuses $(p<0.05)$ and in general, the extent of glucose elevation in the sera of fetuses from diabetic rats was somewhat higher than that seen in the maternal sera (4.6 versus 3.7 times, respectively).

Serum insulin levels of diabetic rats were markedly reduced as expected (Table 1). In the sera of control fetuses from diabetic rats, the levels of insulin were higher than those in control fetuses from non-diabetic rats $(p<0.05)$. This finding demonstrates the effect of hyperglycaemia on insulin release from the fetal pancreas. In the sera of STZ-treated fetuses, the levels of insulin were markedly decreased compared with non-treated fetuses; the low insulin level in these fetuses was not significantly different whether derived from diabetic or non-diabetic maternal rats.

STZ treatment of fetuses from non-diabetic rats caused a marked reduction in pancreatic insulin content to less than one-third that of control fetuses (Table 1). In control fetuses from diabetic rats, the pancreatic insulin content was lower than that in fetuses from non-diabetic rats, most probably due to over-secretion as a result of protracted hyperglycaemia stimulus (evident from the prevalent fetal hyperinsulinaemia). Treatment of fetuses from diabetic rats with STZ caused a further reduction in their pancreatic insulin content, but since the basal content was already decreased, the STZ effect was smaller than in the case of fetuses from non-diabetic mothers. The pancreatic insu- lin content was also somewhat lower in STZ-treated fetuses from diabetic mothers compared with those from non-diabetic mothers $[(p<0.05)]$.

\section{Weight of placentas, fetuses and fetal liver and their glycogen content}

Treatment of fetuses with STZ was without effect on the placental content of glycogen (Table 2). Placental glycogen rose threefold as a result of maternal diabetes, but the intrafetal STZ injection affected neither the low glycogen content in control rats nor the high content in diabetic rats.

In contrast, fetal liver glycogen was considerably reduced as a result of STZ administration. The hepatic glycogen in the STZ-treated fetuses from non-diabetic rats was significantly lower than in those from diabetic rats $(p<0.01)$. This was probably related to the fact that the initial hepatic glycogen level in the control fetuses from diabetic (hyperglycaemic) rats was higher than in fetuses from non-diabetic rats $(p<0.05)$.

STZ administration was also associated with a significant decrease in fetal body weight (7-9\%) and fetal liver weight $(20-24 \%)$, both in non-diabetic and diabetic pregnant rats. The decrease in liver weight was prominent as indicated by the decrease in liver/fetal body weight ratio, which was significant in fetuses of nondiabetic rats $(p<0.05)$, but fell short of statistical significance in the diabetic rats.

The placental weight was only slightly increased in STZ-treated fetuses from non-diabetic and diabetic rats. This was reflected in an increase in placental/fetal weight ratio in the case of STZ-treated fetuses from non-diabetic rats $[(p<0.05)]$.

\section{Effect of insulin administration on substrate incorporation into glycogen of placenta and fetal liver}

To ascertain the reversibility of the STZ-induced fetal insulin deficiency with respect to glycogen synthesis, insulin was administered intrafetally to STZ-treated fetuses. The effect of insulin was assessed by the determination of incorporation of ${ }^{3} \mathrm{H}_{2} \mathrm{O}$ label and of $\mathrm{U}-\left[{ }^{14} \mathrm{C}\right]-$ glucose into glycogen, which were injected into the maternal rats (Table 3 ).

The results show clearly that within $6 \mathrm{~h}$ of insulin administration a threefold increase in the incorporation of both substrates was evident in fetal glycogen, whereas only a slight non-significant increase was observed in the placenta. It may be added that these results were obtained in the face of relatively small variations in the specific activity of the precursor pools: specific activity in maternal and fetal serum water varied between 73.6 and $95.2 \times 10^{6} \mathrm{dpm} / \mathrm{ml}$ in the case of $\left[{ }^{3} \mathrm{H}\right]$ and between 24.5 and $36.9 \times 10^{3} \mathrm{dpm} / \mathrm{ml}$ in the case of $\left[{ }^{14} \mathrm{C}\right], 6 \mathrm{~h}$ after the label injection.

In the experiment recorded in Table 3, all fetuses of non-diabetic rats were STZ-treated. Fetuses not injected 
Table 4. Distribution of glycogen between the fetal and maternal parts of the placenta on day 21.5 of gestation

\begin{tabular}{|c|c|c|c|c|c|}
\hline Pregnant rats & Fetuses & \multicolumn{3}{|c|}{ Placental glycogen content $(\mathrm{mg} / \mathrm{g})$} & $\begin{array}{l}\text { Fetal/maternal } \\
\text { concentration } \\
\text { ratio }\end{array}$ \\
\hline Diabetic & $\begin{array}{l}\text { Control } \\
\text { STZ-treated }\end{array}$ & $\begin{array}{l}6.5 \pm 0.7 \\
6.3 \pm 0.5\end{array}$ & $\begin{array}{l}9.6 \pm 0.8 \\
9.3 \pm 0.7\end{array}$ & $\begin{array}{l}4.6 \pm 0.6 \\
4.3 \pm 0.5\end{array}$ & $\begin{array}{l}0.48 \pm 0.05 \\
0.46 \pm 0.05\end{array}$ \\
\hline
\end{tabular}

Values are mean \pm SEM for $8-10$ placentas in each group. Fetal part comprised $58.5 \pm 1.5 \%$ of total placental weight in control rats and $61.2 \pm$ $1.9 \%$ in diabetic rats

Table 5. Activity of placental glycogen synthase and glycogen phosphorylase STZ-treated and control fetuses

\begin{tabular}{|c|c|c|c|c|c|}
\hline \multirow[t]{3}{*}{$\begin{array}{l}\text { Pregnant } \\
\text { rats }\end{array}$} & \multirow[t]{3}{*}{ Fetuses } & \multicolumn{2}{|c|}{$\begin{array}{l}\text { Glycogen synthase } \\
\left(\text { nmol } \cdot \min ^{-1} \cdot \mathrm{mg}^{-1}\right)\end{array}$} & \multirow{2}{*}{\multicolumn{2}{|c|}{$\begin{array}{l}\text { Glycogen } \\
\text { phosphorylase } \\
\left(\mathrm{nmol} \cdot \mathrm{min}^{-1} \cdot \mathrm{mg}^{-1}\right)\end{array}$}} \\
\hline & & \multirow{2}{*}{$\begin{array}{l}\text { With glu- } \\
\text { cose-6- } \\
\text { phosphate } \\
(10 \mathrm{mmol} / 1)\end{array}$} & \multirow{2}{*}{$\begin{array}{l}\text { Without } \\
\text { glucose- } \\
\text { 6-phos- } \\
\text { phate }\end{array}$} & & \\
\hline & & & & $\begin{array}{l}\text { With AMP } \\
(2 \mathrm{mmol} / 1)\end{array}$ & $\begin{array}{l}\text { Without } \\
\text { AMP }\end{array}$ \\
\hline \multirow[t]{2}{*}{ Control } & Control & 7.1 & 0.5 & 48.2 & 44.0 \\
\hline & $\begin{array}{l}\text { STZ- } \\
\text { treated }\end{array}$ & 6.1 & 0.4 & 41.8 & 38.9 \\
\hline \multirow[t]{2}{*}{ Diabetic } & Control & 9.8 & 0.4 & 66.3 & 47.2 \\
\hline & $\begin{array}{l}\text { STZ- } \\
\text { treated }\end{array}$ & 9.6 & 0.5 & 66.1 & 49.5 \\
\hline
\end{tabular}

The data are representative of several similar experiments

with STZ were not left as controls in order to avoid having three groups of differently treated fetuses in one host. In several experiments, incorporation of ${ }^{3} \mathrm{H}_{2} \mathrm{O}$ and $\mathrm{U}-\left[{ }^{14} \mathrm{C}\right]$-glucose was, therefore, measured in non-diabetic rats with non-STZ-treated fetuses under the same conditions. The incorporation into fetal liver glycogen of $\left[{ }^{3} \mathrm{H}\right]$ label varied from 12 to $18 \mathrm{dpm} / \mathrm{mg}$ tissue and of $\left[{ }^{14} \mathrm{C}\right]$ label from 16 to $28 \mathrm{dpm} / \mathrm{mg}$ tissue. These values were within $30 \%$ of the mean incorporation into the glycogen of insulin-treated STZ fetuses listed in Table 3, indicating that treatment with insulin was effective in promoting the incorporation of both labels at a rate within the range of that of control fetuses. On the other hand, incorporation into placental glycogen of control fetuses was similar to that recorded in Table 3 for both insulintreated or non-treated STZ-fetuses.

\section{Distribution of glycogen within the placenta}

The distribution of glycogen between the 'fetal' and 'maternal' parts of the placenta is shown in Table 4. It may be seen that the glycogen concentration in the 'fetal' part of placenta both from non-diabetic and diabetic rats was generally much lower than that in the "maternal' part, although it was relatively higher in diabetic rats. This distribution may be related to the glucose gradient across the placenta (Table 1) and to fetal hyperglycaemia in diabetic rats.

STZ-treatment of the fetuses, accompanied by fetal hypoinsulinaemia, did not significantly change the dis- tribution of glycogen in favour of the 'maternal' part of the placenta, either in non-diabetic or in diabetic rats in which the total placental glycogen content was markedly elevated.

\section{Placental glycogen synthase and phosphorylase}

Maternal diabetes induced a rise in the total placental activity of glycogen synthase and of phosphorylase assayed in the presence of glucose-6-phosphate and 5-AMP, respectively (Table 5), as reported previously [8]. However, neither in non-diabetic nor in diabetic rats, the induction of fetal hypoinsulinaemia by STZtreatment did appreciably affect the respective low or high activities of glycogen synthase or phosphorylase in the placenta.

\section{Discussion}

It has been demonstrated previously that glycogen accumulates in the placenta of diabetic mothers [8-14] despite the prevalent insulin deficiency. This led us to suggest that the placenta is an insulin-independent tissue, at least with respect to glycogen metabolism, and that hyperglycaemia as such is the causative factor for glycogen accumulation [8]. Our present results strengthen this contention by showing that fetal hypoinsulinaemia, induced by STZ injection, did not affect the placental glycogen content, whether normal in non-diabetic pregnant rats, or elevated in diabetic rats. In contrast, a marked reduction in the liver glycogen content was observed in the STZ-treated fetuses, attesting that fetal insulin deficiency was effective in curtailing hepatic glycogen synthesis and/or promoting its degradation, unrelated to the availability of glucose.

Glycogen synthesis was assessed using U- $\left[{ }^{14} \mathrm{C}\right]$-glucose [25] and ${ }^{3} \mathrm{H}_{2} \mathrm{O}$ [26]. The rate of incorporation of $\left[{ }^{3} \mathrm{H}\right]$ into hepatic glycogen reflects changes in metabolic and hormonal conditions, including STZ-diabetes [26]. This method has the advantage of independence of the size of the precursor pools, since the concentration of the radio-tracer remains nearly constant during the experimental period and it was demonstrated that the ratio of $\left[{ }^{3} \mathrm{H}\right]$ atoms incorporated into glucose units of glycogen was $\sim 3$ in all conditions [26]. Our observation that insu- 
lin promoted to the same extent the incorporation of simultaneously administered $\left[{ }^{3} \mathrm{H}\right]$ and $\left[{ }^{14} \mathrm{C}\right]$ labels into fetal liver glycogen is in accord with the established validity of this method for assessment of the absolute rates of glycogen synthesis [26]. The results clearly indicate, therefore, that insulin administration to STZ-treated fetuses reversed the impaired glycogen synthesis in fetal liver, whereas glycogen synthesis in the placenta was not affected.

Fetal liver weight was significantly decreased in the STZ-treated fetuses and their body weight was also lower compared with control fetuses. However, the decrease in fetal liver weight exceeded the decrease in fetal body weight. It may be concluded, therefore, that the decrease in fetal liver weight and in its glycogen content are the salient features of fetal diabetes. The liver of the STZ-injected fetuses appeared mature without morphological changes [27] and any direct inhibitory effect of STZ is unlikely. Although STZ was reported to inhibit fetal organogenesis [28], this effect was obtained in cultures in vitro of 10-day embryos incubated for $24 \mathrm{~h}$ in the presence of very high STZ concentration $(1 \mathrm{mg} / \mathrm{ml})$ [28]. Such an effect cannot be extrapolated to 19-20-day-old fetuses weighing $4 \mathrm{~g}$ and receiving $240 \mu \mathrm{g} \mathrm{STZ}$ which, at this dose, has a specific pancreatotoxic effect and a very short half-life in vivo. The restoration of hepatic glycogen synthesis by insulin indicates that the hepatic effects should be attributed to hypoinsulinaemia.

Our observation that fetal hypoinsulinaemia was associated with decreased fetal weight gain is concordant with the findings in human newborns with pancreatic agenesis [29] and congenital absence of islet cells [30]. In addition, Girard et al. [31] reported a positive correlation between body weight and fetal insulin concentration on day 20 of gestation of normal rats and Gruppuso et al. [32] showed that hypoglycaemia, caused by insulin infusion to pregnant mothers, resulted in fetal hypoinsulinaemia and growth retardation.

Lack of effect of fetal hypoinsulinaemia on glycogen distribution within the placenta can also be interpreted as supportive for the conclusion that placental glycogen metabolism is glucose rather than insulin-dependent. In contrast to the lack of correlation between fetal serum insulin and glycogen in the 'fetal' part of the placenta, the mean fetal/maternal serum glucose ratios $(0.5-0.6)$ and the mean distribution of glycogen between the 'fetal' and 'maternal' parts of the placenta $(0.3-0.5)$ were roughly similar both in the normoglycaemic and hyperglycaemic situation (compare Tables 1 and 4).

The fetal part of the placenta is exposed to the influence of fetal insulin, which is relatively high during the last days of intrauterine life in fetuses from non-diabetic, and even more so in those from diabetic mothers [15-19]. Posner et al. [33] have shown specific insulinbinding activity on the 'fetal' side of rat placenta, which becomes considerably higher at term than in early ges- tation. However, despite availability of insulin and its receptors, glycogen content in the 'fetal' part of placenta was always lower than in the 'maternal' part. Placental glycogen did not decrease in the hypoinsulinaemic STZ-treated fetuses from non-diabetic rats and even during the ambient hyperglycaemia of maternal diabetes, the STZ-induced fetal hypoinsulinaemia was not effective in preventing the accumulation of glycogen in the 'fetal' part of the placenta.

Unlike the situation in diabetic mothers, the concentration of fetal serum glucose was not increased by the STZ-induced fetal hypoinsulinaemia. This may be due to incomplete development of the fetal liver enzyme of gluconeogenesis which fails to become activated by insulin deficiency. Mencher et al. [27] have reported an increase in fetal hepatic soluble phosphoenolpyruvate carboxylase activity in STZ-treated fetuses, but we did not find any increase in liver glucose-6-phosphatase activity in such fetuses (unpublished observations). Any glucose possibly produced by fetal liver, and not utilized by the under-insulinized fetal tissues, would be diluted in the large maternal glucose pool, thereby preventing the expression of fetal diabetes by hyperglycaemia. However, the observation that in rats with STZtreated fetuses the fetal/maternal serum glucose ratio was somewhat increased (Table 1), provides a hint that fetal hypoinsulinaemia might have been, to a small extent, responsible for fetal glucose under-utilization or increased production.

Acknowledgement. The excellent technical assistance of Mrs. S. Khassis, Mrs. S. Yosha and Mrs. B. Morag is gratefully acknowledged. This work was supported by a grant from the Rozel Herzog/Erna Joseph Memorial Fund and the Joint Research Fund of the Hebrew University and Hadassah, Jerusalem. Streptozotocin was kindly provided by Dr. W. E. Dulin, Upjohn, Kalamazoo, MI, USA.

\section{References}

1. Miller TA Jr, Larner J (1973) Mechanism of hepatic glycogenesis by insulin. J Biol Chem 248: 3483-3488

2. Stalmans W (1976) The role of the liver in the homeostasis of blood glucose. Curr Top Cell Regul 11: 51-97

3. Villar-Palasi C, Larner J (1961) Insulin treatment and increased UDPG-glycogen transglucosylase activity in muscle. Arch Biochem Biophys 94: 436-439

4. Demers LM, Gabbe SG, Villee CA, Greep RO (1972) The effects of insulin on human placental glycogenesis. Endocrinology 91: 270-275

5. Hauguel S, Cedard L (1979) Stimulation de l'activite glycogene synthetase G-6-P independante dans le placenta humain. CR Acad Sci Paris 288: 507-520

6. Coltart TM, Bateman C (1975) Carbohydrate-induced lipogenesis in the human placenta of normal and diabetic pregancies. Biol J Obst Gynec 82: 471-475

7. Szabo AJ, Gimaldi RD (1970) The effect of insulin on glucose metabolism of the incubated human placenta. A, J Obstet Gynecol 106: $75-78$

8. Barash V, Gutman A, Shafrir E (1983) Mechanism of placental glycogen deposition in diabetes in the rat. Diabetologia 24: 63-68 
9. Abramovici A, Sport S, Prager R, Shaltiel A, Laron Z, Liban E (1978) Glycogen metabolism in the placenta of streptozotocin diabetic rats. Horm Metab Res 10: 195-199

10. Hagerman DD (1926) Metabolism of tissues from pregnant diabetic rats in vitro. Endocrinology 70: 88-94

11. Gewolb IH, Barret C, Warshaw IB (1983) Placental growth and glycogen metabolism in streptozotocin diabetic rats. Pediatr Res 17: $587-591$

12. Diamant YZ, Metzger, BE, Freinkel N, Shafrir E (1982) Placental lipid and glycogen content in human and experimental diabetes mellitus. Am J Obstet Gynecol 144: 5-11

13. Gabbe SG, Demers LM, Greep RO, Villee CA (1972) Placental glycogen metabolism in diabetes mellitus. Diabetes 21:1185-1191

14. Heikensjold F, Gemzell CA (1957) Glycogen content in the placenta of diabetic mothers. Acta Paediatr Scand 46: 74-80

15. Blazquez E, Lipshaw LA, Blazquez M, Foa PP (1975) The synthesis and release of insulin in fetal, nursing and young adult rats: Studies in vivo and in vitro. Pediatr Res $9: 17-25$

16. Cohen AM, Turner RC (1972) Plasma insulin in the rat. Biol Neonate 21: 107-111

17. Girard JR, Kervran A, Soufflet E, Assan R (1974) Factors affecting the secretion of insulin and glucagon in the rat fetus. Diabetes $23: 310-317$

18. De Gasparo M, Milner RDG (1980) The timing of fetal B-cell hyperplasia in diabetic rat pregnancy. Diabetologia 19: 54-57

19. Kervran A, Guillaume M, Jost A (1978) The endocrine pancreas of the foetus from diabetic pregnant rat. Diabetologia 15:387-393

20. Portha B, Levacher C, Picon L, Rosselin G (1974) Diabetogenic effect of streptozotocin in the rat during the perinatal period. Diabetes 23: 889-895

21. Diamant YZ, Shafrir E (1978) Placental enzymes of glycolysis, gluconeogenesis and lipogenesis in the diabetic rat and in starvation. Diabetologia 15: 481-485

22. Lowry OH, Rosebrough NJ, Farr AL, Randall RJ (1951) Protein measurement with Folin phenol reagent. J Biol Chem 193: 265-275

23. Johnson YA, Fusaro RM (1964) An enzymic method for the quantitative determination of micro quantities of glycogen. Anal Biochem 7:189-191
24. Gutman A, Schramm H, Shafrir E (1967) Adipose tissue glycogen, turnover and characterization after labeling with glucose in vivo. Israel J Med Sci 3: 427-439

25. Devos P, Hers HG (1974) Glycogen metabolism in the liver of the foetal rat. Biochem J 140:331-340

26. Postle AD, Bloxham DP (1980) The use of tritiated water to measure absolute rates of hepatic glycogen synthesis. Biochem J 192: $65-73$

27. Mencher D, Shouval D, Reshef L (1979) Premature appearance of hepatic phosphoenolpyruvate carboxykinase in fetal rats, not mediated by adenosine $3^{\prime} 5^{\prime}$ monophosphate. Eur J Biochem 102: 489-495

28. Deuchar EM (1978) Effects of streptozotocin on early rat embryos grown in culture. Experientia 34: 84-85

29. Lemons JA, Ridenour R, Orsini EN (1979) Congenital absence of the pancreas and intrauterine growth retardation. Pediatrics 64 : $225-257$

30. Dodge JA, Lawrence KM (1977) Congenital absence of islets of Langerhans. Arch Dis Childh 52: 411-413

31. Girard JR, Rientort M, Kervran A, Jost A (1976) Hormonal control of fetal growth with particular reference to insulin and growth hormone. In: Roth G, Bratteby LE (eds) Perinatal medicine. Almquist \& Wiksell International, Stockholm, pp 197-202

32. Gruppuso PA, Migliori R, Susa JB, Schwartz R (1981) Chronic maternal hyperinsulinemia and hypoglycemia. Biol Neonate 40: $113-120$

33. Posner BI (1974) Insulin receptors in human and animal placental tissue. Diabetes 23: 209-217

Received: 11 September 1984

and in revised form: 28 January 1985

Professor E. Shafrir

Department of Biochemistry

Hadassah University Hospital

P.O. Box 12000

Jerusalem 91120, Israel 